\title{
Induction of Callus Tissues Initiation from Different Somatic Organs of Rice Plant by Various Concen- tration of 2.4-dichlorophenoxy acetic acid ${ }^{1}$
}

\author{
L. Wu and H.W. Li ${ }^{2}$ \\ Institute of Botany, Academia Sinica Nankang, Taipei \\ Taiwan, Republic of China
}

Received January 17, 1970

\section{Introduction}

Somatic tissues from a wide variety of dicotyledons have been grown in vitro as callus tissues which were induced from different organs. Most of these attempts to culture comparable tissues from monocotyledonous have been successful in some species in the past but so far we are aware of not with rice plant.

Carter and Schwarting (1958) attempted to obtain callus from nodes, endosperm, and young embryos of rye but they were successful only with the embryos. Nickle (1964) cultured internodal parenchyma tissues from the stem of several sugarcanes. Mascardnhas, Sayagaver and Jagannathan (1965) obtained callus from maize roots. This callus had an absolute requirement for diphenylurea. Tamaoki and Ullstrup (1958) using small explant of intercalary meristem of corn stem obtained callus, but their subcultures did not grow. Webster (1966) established callus from germinating oats seeds cultured the Chysanthemum nematode upon the callus. Carter, Yamada and Takahashi (1967) found that oat-callus induction and growth were very sensitive to auxin but relatively unaffected by kinetin. Trione Jones and Metzer obtained callus tissue from the cotyledonary node of wheat and grew well there after (1968). The tissue culture of rice has been studied in recent years. However the callus can be induced only from the embryo (Yamada, Tanaka and Takahashi 1967).

Corn endosperm was first cultured by La Rue (1949) and subsequently by many others (Piezur 1952, Sternkeimer 1954, Strans and La Rue 1954, 1954, Tamaoki and Ullstrup 1958). Norstog (1965) cultured the endosperm of rye grass. These endosperm cultures are triploid tissues which do not differentiate to form recognizable organs in culture. All in all so far there have been a few reports of successful culture of cells from monocotyledonous plants.

1 This study was partly supported by the National on Science Development of Republic of China.

2 Assistant Research Fellow and Research Fellow of the Institute of Botany, Academia Sinica. 
This paper gives the result of our study of tissue culture of rice plant of $O$. sativa as the methods for inducing the formation of callus from different somatic organs using different concentrations of $2.4-\mathrm{D}$ as well as the anatomical studies of the origin of these cells from which callus tissues are originated.

\section{Materials and methods}

Various organs of seedlings and older rice plants of $O$. sativa var. Taichung No. 65 were used in this experiments. Dehusked seeds and older plant organs were washed and surface sterilized in 1 percent sodium hypochloride for $15 \mathrm{~min}$ and rinsed four times with sterile distilled water. The sterilized seeds were soaked in sterile distilled water for 12 hours, then they were implanted on the selected medium. The modified medium contained $(\mathrm{mg} / \mathrm{l}) ; \mathrm{NH}_{4} \mathrm{NO}_{3}, 1000 ; \mathrm{Ca}\left(\mathrm{NO}_{3}\right)_{2} \cdot 4 \mathrm{H}_{2} \mathrm{O}, 10000 ; \mathrm{KNO}_{3}, 800 ; \mathrm{KCl}, 65$; $\mathrm{MgSO}_{4} \cdot 7 \mathrm{H}_{2} \mathrm{O}, 370 ; \mathrm{NaH}_{2} \mathrm{PO}_{4}, 16.5 ; \mathrm{Fe}_{2}\left(\mathrm{SO}_{4}\right), 2.5 ; \mathrm{Na}_{2}-\mathrm{EDTA}, 13.5 ; \mathrm{ZnSO}_{4} \cdot$ $7 \mathrm{H}_{2} \mathrm{O}, 3.8 ; \mathrm{H}_{3} \mathrm{BO}_{3}, 4.5$; $\mathrm{KI}, 0.75$; glycine, 3 ; thiamine, 0.1 ; pyriodoxine, 0.1 ; nicotinic acid 0.5 ; sucrose, 20,000; yeast extract, 5000; agar, 8,000. Then the growth regulators such as kinetin, 2.4-D and 3-indolyl-acetic acid (IAA) were added for specific purpose. With excised nodes and young leaf sheath of older plants they were placed on the surface of agar medium containing $8 \mathrm{ppm} 2.4-\mathrm{D}$ in addition for callus induction. Wherease with soaked seeds they were on the medium containing $0.5 \mathrm{ppm} 2.4-\mathrm{D}$ for the callus induction from roots. When the medium containing $6 \mathrm{ppm} 2.4-\mathrm{D}$ callus induction could be obtained from scutellum and cotyledonous nodes. On the medium containing $2 \mathrm{ppm} 2.4-\mathrm{D}$ the coleoptile could be grown to the length of 2 to 4 centimeters. The excised coleoptile was then transfered to the medium containing $6 \mathrm{ppm} 2.4-\mathrm{D}$ for callus induction. All the cultures were incubated in dark room at $28^{\circ} \mathrm{C}$.

For the purpose of anatomic observation of the initiation of callus tissues the paraffin microtome sections were obtained and stained with hematoxylin as were as fast green.

\section{Results}

Excised young leaf-sheath and nodes were incubated three weeks (in darkness at $28^{\circ} \mathrm{C}$ ) on the medium containing $8 \mathrm{ppm} \mathrm{2.4-D.} \mathrm{The} \mathrm{outer}$ epidermis of the excised leaf-sheath and nodes were proliferated to form callus tissues (Fig. 1A, B). However, the inner epidermis of leaf-sheath sometimes were found to form callus. The callus formation usually limitted in the node region. Although we tried to induce callus from internode, it had never been succeeded. A cross section of the callus induced leaf-sheath shows many groups of callus which proliferate from the external region of immature vascular bundles (Fig. 1F). An enlarged photograph of transvers section of the vascular bundle of the callus induced leaf-sheath (Fig. 1G) shows that the callus meristematic cells are initiated from the external meristematic cells located 

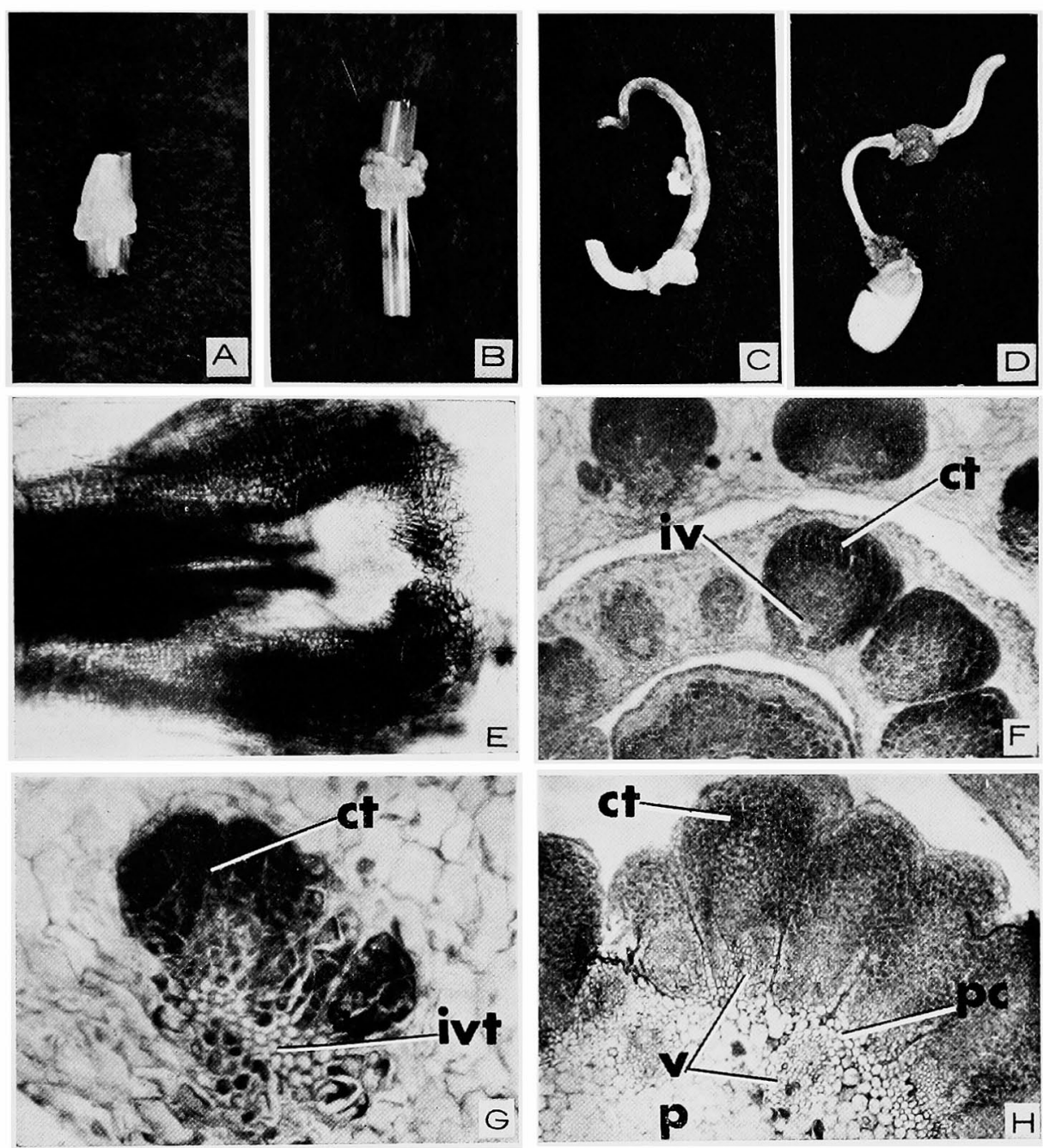

Fig. 1. A, a mass of callus formed from the leaf-sheath which was excised from the older rice plant and incubated on the agar medium containing $8 \mathrm{ppm}$ 2.4-D. $\times 6$. B, callus tissue proliferated from the excised node of older rice plant. The induction medium containing $8 \mathrm{ppm}$ 2.4-D. $\times 2$. C, masses of callus tissues burst out from the epidermis of the excised coleoptile using medium containing $6 \mathrm{ppm} 2.4-\mathrm{D}$. $\times 4$. D, two groups of callus are differentiated from the scutellum and cotyledonous node using medium containing $2 \mathrm{ppm} 2.4-\mathrm{D} . \times 4$. $\mathrm{E}$, a root tip is swollen and collasped to form callus using medium containing $0.5 \mathrm{ppm}$ 2.4-D. $\times 100$. F, transverse section of callus induced young leaf-sheath of rice showing masses of callus tissue grow from the external region of immature vascular bundles. $\times 200$. $G$, an enlarged photomicrograph of differentiating vascular bundle of callus induced leafsheath showing a group of meristematic cells initiated from the meristematic cells near the immature vascular tissues. $\times 400 . \mathrm{H}$, a transverse section of callus induced node of rice showing callus tissues formed the meristematic cells of procambium. $\times 200$. iv: immature vascular bundle, ct: callus tissue, pc: procambium, v: vascular bundle, ivt: immature vascular tissue, p: pith. 
very closely by the immature vascular tissues of the differentiating vascular bundle. A cross section of callus induced node shows that masses of callus tissues arise from the meristematic cells of procambium (Fig. 1H).

The excised coleoptiles were implanted in the medium containing $6 \mathrm{ppm}$ $2.4-\mathrm{D}$ and incubated in darkness at $28^{\circ} \mathrm{C}$ for three weeks. The surface of the coleoptiles were proliferated to form callus (Fig. 1C). Similarly the calli
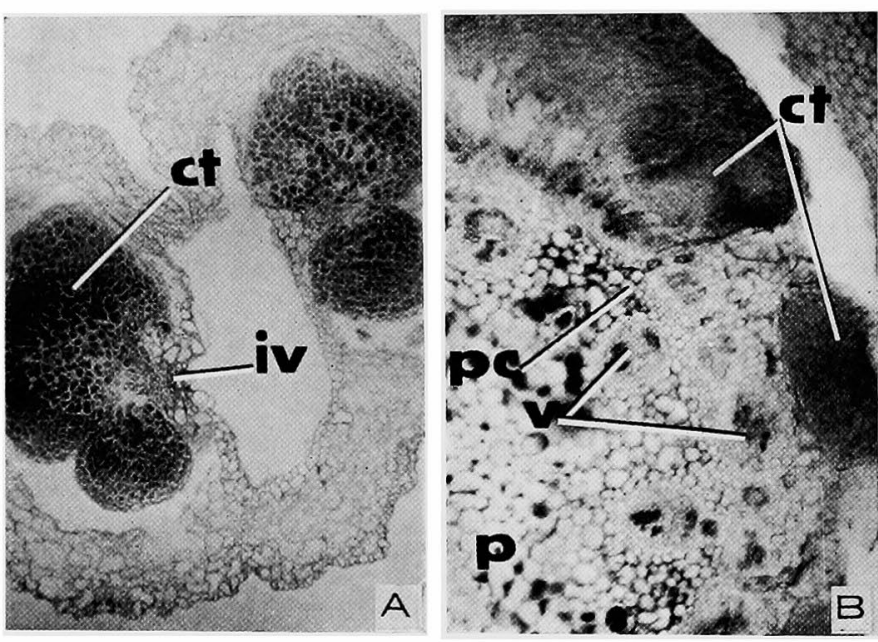

were formed from cotyledonous node and scutellum of germinated seeds which were incubated in the medium containing $2 \mathrm{ppm} 2.4-\mathrm{D}$ (Fig. 1D). Further investigations show that the callus tissues were initiated from the meristematic cells near the differentiating immature vascular bundle of
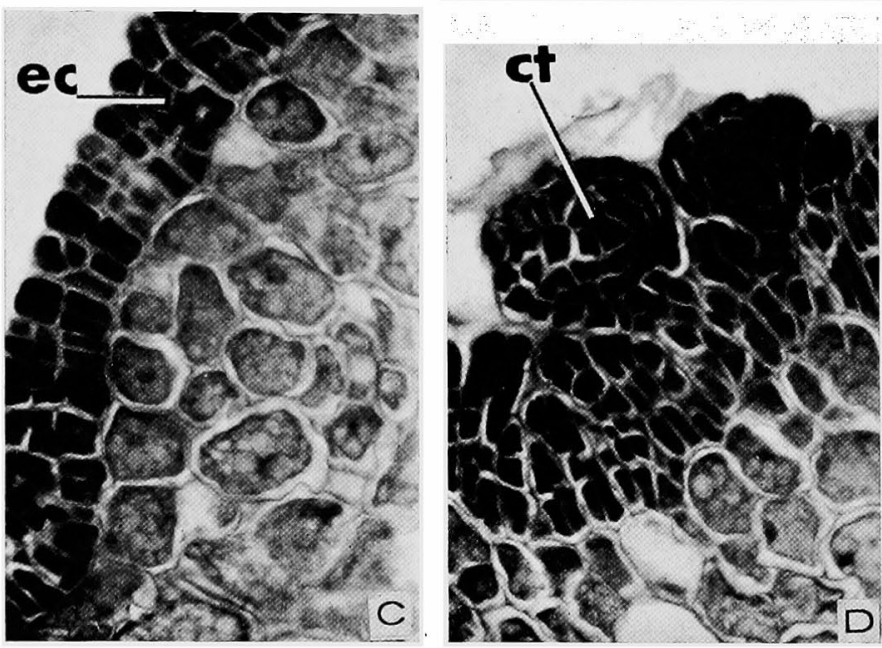

Fig. 2. A, a transverse section of coleoptile of rice showing two groups of callus tissues was formed from the meristematic cells of the external differentiating vascular bundle. $\times 200$. B, a transverse section of callus induced cotyledonous node of rice showing callus tissues grow from the procambium and the external phloem region. $\times 200$. C, a section of the scutellum of rice embryo cultured on the medium containing $6 \mathrm{ppm}$ 2.4-D showing the epidermis cells being activated in to meristematic cells. $\times 400$. $D$, a section of callus tissues are initiated from the activated epidermis cells of scutellum. $\times 400$. the coleoptile (Fig. 2A). In cotyledonous node the callus tissues initiated from the meristematic cells of procambium sometimes initiated from the peripherial meristematic tissues of the external phloem region (Fig. 2B). However, the callus tissues were formed by the vigorous cell divisions of the epidermis cells of the scutellum (Figs. 2C, D).

The meristematic portion of the root tips of seedlings were swollen to 
form callus (Fig. 1E) after being planted on the medium containing $0.5 \mathrm{ppm}$ $2.4-\mathrm{D}$ and incubated in darkness at $28^{\circ} \mathrm{C}$.

All callus tissues induced from different somatic organs had been sub. cultured successfully on the basic medium which supplemented with kinetin $(2 \mathrm{ppm}), \mathrm{IAA}(2 \mathrm{ppm})$ and $2.4-\mathrm{D}(4 \mathrm{ppm})$.

\section{Discussion}

In the case of seeds, they must be presoaked for 12 hours in order to induce callus formation. When the seeds are not presoaked a mass of callus tissue will be proliferated from embryo, having the rest of the organs to be inhibited from further development such as coleoptile, hypocotyle and roots. Since only the mass of callus tissues are formed, the origin of the tissue from which the callus is originted remaines unknown.

For callus differentiation kinetin and IAA seem to be not essential in the medium. However $2.4-\mathrm{D}$ is necessary hormone required.

The variation of the concentration of $2.4-\mathrm{D}$ in the medium is sensitive for the callus induction from different organs. When the concentration is low $(0.5 \mathrm{ppm})$ only the root tip cells will form callus the other organs would differentiated and grow as usual. When the concentration of $2.4-\mathrm{D}$ was increased to $2 \mathrm{ppm}$ root differentiation stopped, coleoptile and hypocotyle seem not to be effected and they continue to differentiate. Callus tissues can be frequently initiated from scutellum and cotylendonous nodes. Coleoptile may increase up to 4 centimeter in length. The lengthened coleoptile can be excised and planted on the medium containing $6 \mathrm{ppm} 2.4-\mathrm{D}$ callus tissues would then be initiated.

Anatomical studies showed that the initiation of callus tissues in leafsheath and coleoptile are initiated from the meristematic cells located very closely by the immature vascular bundles. From that, the callus induction is easier to be obtained from leaf-sheath of young seedlings. On the contrary it is harder to obtain a callus from young leaf-sheath of an older plant. It was tried to induce callus from the old leaf-sheath but there was no success.

Callus tissue can be induced from any node of rice stem even from nodes of panicles. The initiation of callus in nodes seems to be similar to the initiation of the adventitious roots which are initiated near the differentiating vascular tissue or arise directly from procambium (Katayama).

\section{Summary}

Callus tissues were induced from different somatic organs of $O$. sativa variety Taichung No. 65. Specific 2.4-dichlorophenoxy acetic acid (2.4-D) concentration in a medium is necessary for the induction of callus from different organs. The optium 2.4-D concentration for callus induction from different organs are : $0.5 \mathrm{ppm}$ for roots, $2 \mathrm{ppm}$ for scutellum and cotyledonous 
node, $6 \mathrm{ppm}$ for coleoptile and $8 \mathrm{ppm}$ for stem nodes and leaf-sheath. All cultures were incubated in darkness at $28^{\circ} \mathrm{C}$.

Anatomical studies showed that the initiation of callus tissues from leafand coleoptile are initiated from the meristematic cells located very closely by the immature vascular bundles. The initiation of callus in nodes seems to be similar to those of adventitious roots which are initiated near to the differentiating vascular tissue or directly from the procambium.

\section{Literature cited}

Carew, D. P. and Schwarting, A. E. 1958. Production of rye embryo callus. Bot. Gaz. 119: 237-239.

Carter, O., Yamada, Y. and Takahashi, E. 1967. Tissue culture of oats. Nature 114: 1029-1030.

Trione, E. J., Jones, L. E. and Metzger, R. J. 1968. In vitro culture of somatic wheat callus tissue. Amer. J. Bot. 55(5): 529-531.

La Rue, C. D. 1949. Culture of the endosperm of maize. Amer. J. Bot. 34: 585-586.

Mascarenhas, A.F., Sayagaver, B. M. and Jagannathan, V. 1965. Studies on the growth of callus cultures of $Z e a$ mays. Tissue culture seminar Pro., Univ. Baroada, India.

Nickell, L. G. 1964. Tissue and cell culture of sugar cane-another research tool. Hawaiian Planters Rec. 57: 223.

Nostog, K. J. 1956. Growth of rye-grass endosperm in vitro. Bot. Gaz. 117: 253-259.

Pieczur, E. A. 1952. Effect of tissue culture of maize endosperm on the growth of excised maize embryos. Nature 170: 241-242.

Sternheimer, E. P. 1954. Method of culture and growth of maize endosperm in vitro. Bull. Torry Bot. Ciub 81: 111.

Straus, J. 1954. Maize endosperm growth in vitro II. Morphology and cytology. Amer. J. Bot. 41: 833-839.

Tadda C. and Katayama, Y. 1966. Anatomy of the root of Oryza sativa with emphasis on developmental processes. Seiken Ziho 18: 6-22.

Tamaoki, T. and Ullstrup, A. J. 1958. Cultivation in vitro of excised endosperm and meristem tissues of corn. Bull. Torry Bot. Club 83: 360-272.

Webster, J. M. 1966. Production of oat callus and its susceptibility to a plant parasitic nematod. Nature 212: 1472. 